PERM JOURNAL OF PETROLEUM AND MINING ENGINEERING

ВЕСТНИК ПНИПУ. ГЕОЛОГИЯ. НЕФТЕГАЗОВОЕ И ГОРНОЕ ДЕЛО

ISSN 2224-9923

Volume/ Toм 16 №3 2017

http://vestnik.pstu.ru/geo/

УДК 622.253.3:536.42

Article / Статья

(c) PNRPU / ПНИПУ, 2017

\title{
METHOD FOR SOLVING INVERSE STEFAN PROBLEM TO CONTROL ICE WALL STATE DURING SHAFT EXCAVATION
}

\section{Lev Yu. Levin, Mikhail A. Semin, Oleg S. Parshakov, Evgeniy V. Kolesov}

Mining Institute of the Ural Branch of the Russian Academy of Sciences - Branch of the Federal State Budgetary Institution of Science Perm Federal Research Center of the Ural Branch of the Russian Academy of Sciences (78 Sibirskaya st., Building A, Perm, 614007, Russian Federation)

\section{МЕТОД РЕШЕНИЯ ОБРАТНОЙ ЗАДАЧИ СТЕФАНА ДЛЯ КОНТРОЛЯ СОСТОЯНИЯ ЛЕДОПОРОДНОГО ОГРАЖДЕНИЯ ПРИ ПРОХОДКЕ ШАХТНЫХ СТВОЛОВ}

\section{Л.Ю. Левин, М.А. Семин, О.С. Паршаков, Е.В. Колесов}

Горный институт Уральского отделения Российской академии наук - филиал Федерального государственного бюджетного учреждения науки Пермского федерального исследовательского центра Уральского отделения Российской академии наук (614007, Россия, г. Пермь, ул. Сибирская, 78a)

Received / Получена: 25.04.2017. Accepted / Принята: 18.07.2017. Published / Опубликована: 15.09.2017

\section{Key words:}

artificial ground freezing,

ice wall, freezing column, rock massif, inverse Stefan problem, shafts, heattransfer equation, phase transition, numerical modelling, control

well, incompatibility of input data, approximation, minimization of a functional, gradient decent method, exponential integral function.

\section{Ключевые слова:}

искусственное замораживание грунтов, ледопородное

ограждение, замораживающая колонка, породный массив, обратная задача Стефана, шахтные стволы, уравнение теплопроводности, фазовый переход, численное моделирование, контрольная скважина, несовместность входных данных, аппроксимация, минимизация функционала, метод градиентного спуска, интегральная показательная функция.

\begin{abstract}
Mathematical statement of direct and inverse problem of Stefan for horizontal layer of rock massif with homogenous and isotropic thermophysical properties is presented. It is assumed as a hypothesis that heat transfer in vertical direction is negligible compared to heat exchange in horizontal plane. At the initial moment, the rock massif has a uniform temperature and the temperature on surfaces of freezing columns was the same for all columns and constant in time. A method proposed allows getting an approximate solution of the direct Stefan problem for a single freezing column with a small consumption of computational resources. Based on a proposed method, a high-speed algorithm for solving inverse Stefan problem for the case of a single freezing column is built. An algorithm is based on the gradient descent method. The effect on the solution of of a single freezing column is built. An algorithm is based on the gradient descent method. The effect on the solution of
different types of functions used is analyzed. Functions approximate the temperature field in a cooling zone. It is established that time dependence of the radius of a phase transition front essentially depends on the type of an approximation function. The most preferable is an integral exponential function that is a solution to the one-dimensional heat equation in cylindrical coordinates. Then, proposed technique and algorithm are considered for the case of variety of freezing columns that form circle counter and random number of control wells. Results of the calculation of inverse Stefan problem for conditions of the shaft No. 1 of the mine being under construction at the Petrikovsky ore mining and processing enterprise are presented. The No. 1 of the mine being under construction at the Petrikovsky ore mining and processing enterprise are presented. The
calculation included well inclinometry based on geological data. It was studied how measurements of the temperature made at different wells can affect obtaining solution. Options of interpretation of inconsistency of temperatures measured in control wells are offered. Probabilistic analysis of ice wall thickness is carried out.
\end{abstract}

Представлена математическая постановка прямой и обратной задач Стефана для горизонтального слоя породного массива с однородными и изотропными теплофизическими свойствами. В качестве гипотезы принято, что теплообмен в вертикальном направлении пренебрежимо мал по сравнению с теплообменом в горизонтальной плоскости, в начальный момент времени породный массив имеет однородную температуру, а температура на поверхностях замораживающих колонок одинакова для всех колонок и неизменна во времени. Предложен метод, позволяющий с малыми затратами вычислительных ресурсов получить аппроксимационное решение прямой задачи Стефана для случая одиночной замораживающей колонки. На основании предложенного метода построен скоростной алгоритм решения обратной задачи Стефана для случая одиночной замораживающей колонки, основанный на методе градиентного спуска. Проведен анализ влияния на решение вида используемых функций, аппроксимирующих поле температур в зоне охлаждения. Установлено, что временная зависимость радиуса фронта фазового перехода существенно зависит от выбора аппроксимационной функции, а наиболее предпочтительным является использование интегральной показательной функции, являющейся решением одномерного уравнения теплопроводности в цилиндрических координатах. В дальнейшем предложенные метод и алгоритм распространяются на случай множества замораживающих колонок, образующих круговой контур, и произвольного количества контрольных скважин. Представлены результаты расчета обратной задачи Стефана для условий шахтного ствола № 1 строящегося рудника Петриковского горно-обогатительного комбината с учетом инклинометрии скважин на основании данных геологии. Рассмотрено влияние несовместности измерений температуры несколькими контрольными скважинами на получаемое решение. Предложены варианты интерпретации несовместности измеренных в контрольных скважинах температур, проведен вероятностный анализ толщины ледопородного ограждения.

Lev Yu. Levin (Author ID in Scopus: 16407072500) - Doctor of Engineering, Head of the Department of Aerology and Thermophysics (tel.: +007 342 216 09 69, e-mail: aerolog_lev@mail.ru)

Mikhail A. Semin (Author ID in Scopus: 56462570900) - PhD in Engineering, Research Fellow (tel.: +007 3422165492 , e-mail: mishkasemin@gmail.com). The contact person.

Oleg S. Parshakov - Junior Research Fellow (tel.: +007 34221654 92, e-mail: olegparshakov@gmail.com).

Evgeniy V. Kolesov - Engineer (tel.: +007342 21654 92, e-mail: kolesovev@gmail.com).

Левин Лев Юрьевич - доктор технических наук, заведующий отделом аэрологии и теплофизики (тел.: +007 34221609 69, e-mail: aerolog_lev@mail.ru). Семин Михаил Александрович - кандидат технических наук, научный сотрудник (тел.: +007 34221654 92, e-mail: mishkasemin@gmail.com). Контактное лицо для переписки.

Паршаков Олег Сергеевич - младший научный сотрудник (тел.: +007 34221654 92, e-mail: olegparshakov@gmail.com).

Колесов Евгений Викторович - инженер (тел.: +007 34221654 92, e-mail: kolesovev@gmail.com). 


\section{Introduction}

Artificial freezing of rocks is one of the most universal and reliable ways of vertical shafting in complex hydrogeological conditions [1]. The technique is about drilling of a ring of wells around the designed shaft section and then installation of freezing columns in the wells that provide coolant circulation. After a while a fence that protect the mine against the groundwater entry during its construction is created. A fance consits of the frozen water-containing ground. Effectiveness of such a protection fence, which is called an ice wall, ultimately depends on its sealing and thickness.

Shafting after freezing is allowed to be started only after sealed contour of designed thickness is obtained. At the same time, during the freezing of the rock massif it is important to carry out continuous monitoring of a current state of an ice wall and timely determine the moment when sufficient thickness and contour continuity from the frozen rocks are achieved [2].

During the last years imperfection of existing methods to control the formation of the ice wall and insufficient accuracy of calculations of its parameters have caused problems with not providing the ice wall sealing. That problem has been faced by the mining enterprises that develop such fields of high water cut as Gremyachinskiy Ore Mining and Processing Enterprise of EuroChem Group AG, Garlykskiy Ore Mining and Processing Enterprise of State Concern Turkmenchemistry and Head Office of Verkhnekamskoe deposit of potassium and magnesium salts [3]. As a result, accidents happend during the construction of shafts led to a decrease in the safety of mining and appearance of additional financial costs.

Therefore, today Department of Aerology and Thermophysics of the Urals Branch of the Russian Academy of Sciences introduces a new promising system for determination of sealing and thickness of an ice wall based on the use of fiber optic thermometry technology [3, 4]. This technology allows obtaining the temperature distribution along the depth of control wells located at some distance from the freezing column contour and monitor the current thermal regime of the rock massif at any time.

At that, there is a problem arises of restoring the temperature distribution in the entire rock massif from temperature measurements in control wells, the number of which is usually small (3-5 pieces). Mathematically, this leads to the formulation of the inverse Stefan problem [4].

Before, there was no attention paid to inverse problems of heat conduction (IPHC) and inverse Stefan problem (ISP) in the existing studies of ice wall formation. The mathematical apparatus used to study the formation of ice wall in Russia and abroad represent direct heat conductivity and Stefan's problem only [1, 5-12]. At that, there is a number of studies devoted to the analysis of the correctness of the establishment of IPHC and ISP in the general case $[13,14]$ and analysis of numerical methods for solving IPHC and ISP [15-18]. Two groups of methods for obtaining stable solutions of inverse problems are classically distinguished. Those are self-regulation at which measure of the proximity of the resulting solution is controlled to the exact one by varying the parameters of the computational algorithms, and regularization by the method of A.N. Tikhonov, implying the construction of a regularizing operator, smooth functional and its subsequent minimization [14]. There is a class of descriptive regularization methods presented in papers as well. Additional stabilizing constraints are introduced in those methods for the desired solution [18]. Common drawbacks of existing methods are as follows: algorithmic complexity, significant costs of computing resources and need for additional checks on the convergence and stability of the solution.

The purpose of this paper is to develop a rapid method for solving Stefan's inverse problem for analyzing the formation of an ice wall of mine shafts under construction. The work is relevant due to the necessity to determine actual thickness and continuity of an ice wall on field quickly and with acceptable accuracy. The idea of the work is to determine the approximate analytical form of the temperature distribution in a horizontal array section for the case of many wells and its use for solving the Stefan inverse problem. That will be reduced to determination of an obvious dependence for the temperature mismatch function in control wells and its minimization by the gradient descent method.

\section{Mathematical statement of direct and inverse Stefan problems}

The authors consider a horizontal layer of a rock massif with homogeneous and isotropic 
thermophysical properties. It is assumed, that heat exchange in a vertical direction is negligible compared to heat exchange in a horizontal plane. At the initial moment, the rock massif has a uniform temperature $T_{0}$, temperature $T_{w}$ on surfaces of freezing columns is assumed to be the same for all columns and unchanged in time (Fig. 1). It is assumed, that there is a complete conversion of water into ice $[19,20]$.

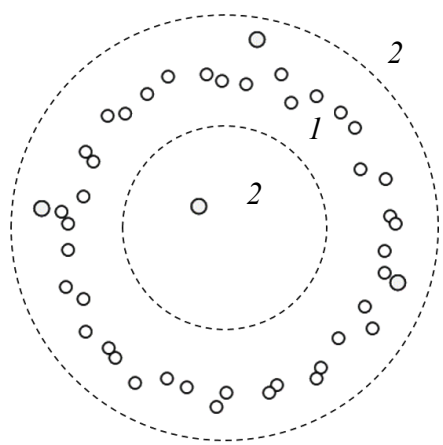

Fig. 1. The contour of freezing columns in the horizontal section of the rock massif: 1 is for the ice zone; 2 is for the cooling zone, dashed line is for the current position of the phase transition boundary

In this case, mathematical statement of the two-dimensional direct Stefan problem in polar coordinates reduces to the following system of equations [5]:

$$
\begin{gathered}
\frac{\partial T_{1}}{\partial t}=\frac{k_{1}}{\rho_{1} c_{1}}\left(\frac{\partial^{2} T_{1}}{\partial r^{2}}+\frac{1}{r} \frac{\partial T_{1}}{\partial r}+\frac{1}{r^{2}} \frac{\partial^{2} T_{1}}{\partial \varphi^{2}}\right), \\
\frac{\partial T_{2}}{\partial t}=\frac{k_{2}}{\rho_{2} c_{2}}\left(\frac{\partial^{2} T_{2}}{\partial r^{2}}+\frac{1}{r} \frac{\partial T_{2}}{\partial r}+\frac{1}{r^{2}} \frac{\partial^{2} T_{2}}{\partial \varphi^{2}}\right), \\
\left.\left(k_{1} \frac{\partial T_{1}}{\partial r}-k_{2} \frac{\partial T_{2}}{\partial r}\right)\right|_{\Gamma_{p h}}=\rho L \frac{d \Gamma_{p h}}{d t}, \\
\left.T_{1}\right|_{\Gamma_{p h}}=\left.T_{2}\right|_{\Gamma_{p h}}, \\
\left.T_{1}\right|_{\Gamma_{w}}=T_{w}, \\
\left.T_{2}\right|_{r \rightarrow+\infty}=T_{0}, \\
t=0: \quad T_{2}=T_{0}, \quad \Gamma_{p h}=\Gamma_{w},
\end{gathered}
$$

where $k_{1}$ is for thermal conductivity of the medium in the ice zone, $\mathrm{W} /\left(\mathrm{m} \cdot{ }^{\circ} \mathrm{C}\right) ; k_{2}$ is for thermal conductivity of the medium in the cooling zone, $\mathrm{W} /\left(\mathrm{m} \cdot{ }^{\circ} \mathrm{C}\right) ; c_{1}$ is for specific heat of the medium in the ice zone, $\mathrm{J} /\left(\mathrm{kg} \cdot{ }^{\circ} \mathrm{C}\right) ; c_{2}$ is for specific heat of the medium in the cooling zone, $\mathrm{J} /\left(\mathrm{kg} \cdot{ }^{\circ} \mathrm{C}\right) ; \rho$ is for medium density, $\mathrm{kg} / \mathrm{m}^{3} ; T_{p h}$ is for phase transition temperature, ${ }^{\circ} \mathrm{C} ; L$ is for specific heat of ice melting, $\mathrm{J} / \mathrm{kg} ; w$ is for moisture content of the massif, $\mathrm{kg} / \mathrm{kg} ; \Gamma_{w}$ is for surface of freezing columns; $\Gamma_{p h}$ is for interface of a phase transition; $R_{v}$ is for the radius of the outer boundary of a computational domain, $\mathrm{m} ; T_{w}$ is for temperature of walls of freezing columns, ${ }^{\circ} \mathrm{C} ; T_{0}$ is for temperature of undisturbed rock massif at the distance, ${ }^{\circ} \mathrm{C}$.

The Stefan coefficient inverse problem is formulated to the direct problem (1)-(7) as described below. Considering that dependence of temperature on time at the surface of control wells $\Gamma_{c w}$ is known

$$
(r, \varphi) \in \Gamma_{c w}: T=T_{c w}(r, t),
$$

it is required to find the values of the thermophysical properties of the rock massif $k_{1}, k_{2}$, $c_{1}, c_{2}, L$ at $0<t \leq T$ and find the function $T(r, \varphi, t)$, which would satisfy the problem (1)-(7).

In addition, restrictions on thermophysical properties of the rock massif that correspond minimum possible and maximum possible values are imposed. Those values are determined on the basis of engineering and geological surveys [21, 22].

\section{Approximation of the direct Stefan problem solution for the case of a single freezing column}

First of all, the present study consider the simplest case of a single freezing column. The goal was to find an approximate analytical solution of the direct Stefan problem for the given case.

In this case, the system (1)-(7) is simplified. The dependence on an angle $\varphi$ disappears and surface $\Gamma_{w}$ of the freezing columns reduces to a circle of radius $r_{w}$.

It is proposed to write the general solution of the system (1)-(7) for the case of a single freezing column in the form of a superposition of local solutions separately for the ice zone and cooling zone. Conjugation of these two local solutions will occur along the boundary of the phase transition $r_{p h}=r_{p h}(t)$.

In the ice zone a logarithm corresponding to the case of quasistationary propagation of heat was considered as the local solution [9]:

$$
T_{1}=T_{w}+\frac{T_{p h}-T_{w}}{\ln \left(r_{p h} / r_{w}\right)} \ln \left(r / r_{w}\right) .
$$


As the preliminary numerical calculations of the direct Stefan problem for the case of a single well have shown, this approximation introduces an error in determination of the radius of an ice wall front by no more than $10 \%$ in the investigated range of times and thicknesses of the ice wall [3].

There were several options of functional forms of local solutions considered in the cooling zone sach as an exponential form, trigonometric form and form of the integral exponential function:

$$
\begin{gathered}
T(r, t)=T_{0}+\left(T_{p h}-T_{0}\right) \times \\
\times \exp \left(-\frac{\left(r-\sqrt{4 a_{2} t \ln \left(\frac{T_{p h}-T_{0}}{T_{w}-T_{0}}\right)}\right)^{2}}{4 a_{2} t}\right), \\
T(r, t)=T_{p h}+\left(T_{0}-T_{p h}\right) \frac{2}{\pi} \operatorname{arctg}\left(-\frac{r-r_{p h}}{\sqrt{4 a_{2} t}}\right), \\
T_{2}=T_{0}+\frac{T_{p h}-T_{0}}{\operatorname{Ei}\left(-\frac{r_{p h}^{2}}{4 a_{2} t}\right)} \operatorname{Ei}\left(-\frac{r^{2}}{4 a_{2} t}\right) .
\end{gathered}
$$

Here $a_{2}$ is for thermal conductivity of the medium in the cooling zone, $\mathrm{m}^{2} / \mathrm{s}$.

The only physically feasible option here is the integral exponential function, which is an elementary solution of the cylindrical onedimensional heat conductivity equation [23]. Only this function ensures the implementation of the law on the conservation of the amount of thermal energy. Two additional cases of local solutions should be interpreted as a purely mathematical technique of selecting an approximation to a solution of the direct Stefan problem for a single freezing column in the cooling zone. At that, the parameter $a_{2}$ for equations (11) and (12) is not anymore the thermal conductivity in the strict sense.

The proposed basis functions (10)-(12) are presented in Fig. 2. Calculation parameters of the problem are temperature of the undisturbed massif $+10{ }^{\circ} \mathrm{C}$, temperature of the surface of freezing columns $-20^{\circ} \mathrm{C}$, calculation time 40 days.

The Fig. 2 shows that an exponential function is sufficiently close to an exact solution of the cylindrical equation of thermal diffusion (integral exponential function). In this case, a trigonometric function underestimates values of temperatures in the cooling zone (up to $1.5^{\circ} \mathrm{C}$ ), but this can be corrected by normalizing the coefficient of thermal conductivity in the formula (10).

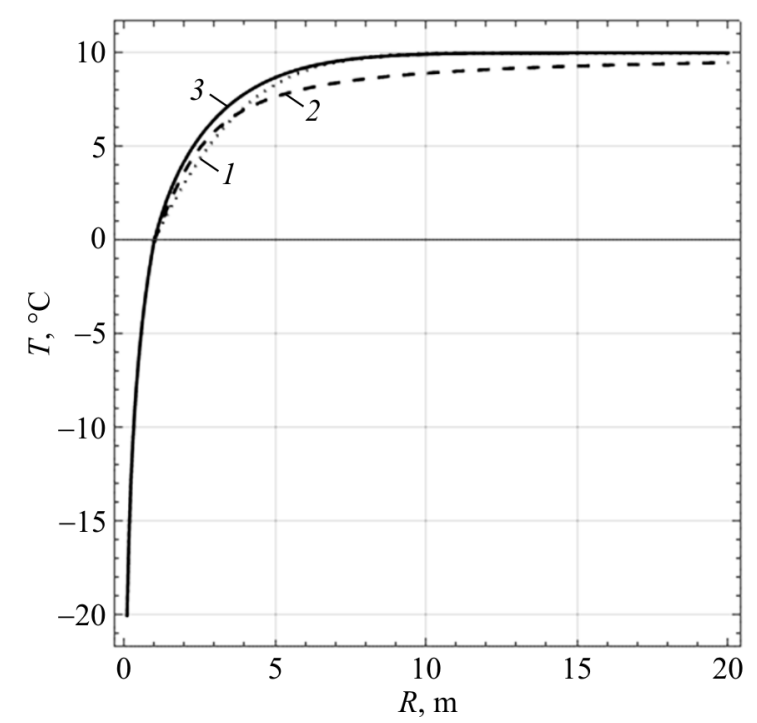

Fig. 2. Approximate solution of the direct cylindrical Stefan problem using various approximating functions in the cooling zone: 1 - exponential form; 2 - trigonometric form; 3 - form of integral exponential function

The approximate analytical solution (9)-(12) should not only correctly reflect the temperature distribution in the zone of ice and cooling but also provide an adequate prediction of the time dynamics of the phase transition front $r(t)$. Function $r(t)$ is determined from the solution of equation (3) after substituting in it the temperature gradients calculated from the function (9) and one of the functions (10)-(12).

The Fig. 3 shows the time dependence of the radius of the phase transition front calculated for each of the functions (10)-(12). The calculation was performed numerically using the explicit $4^{\text {th }}$ order Runge-Kutta method [24]. As it follows from the Fig. 3, all three functions chosen for the cooling zone manage the task of an adequate prediction of time dynamics of the phase transition front (mismatch is less than $6 \%$ ). The strongest estimation for the radius of the phase transition front is given by a solution in the form of an integral exponential function. Thus, it is better to use an integral exponential function to represent the solution when solving only the direct Stefan problem. 


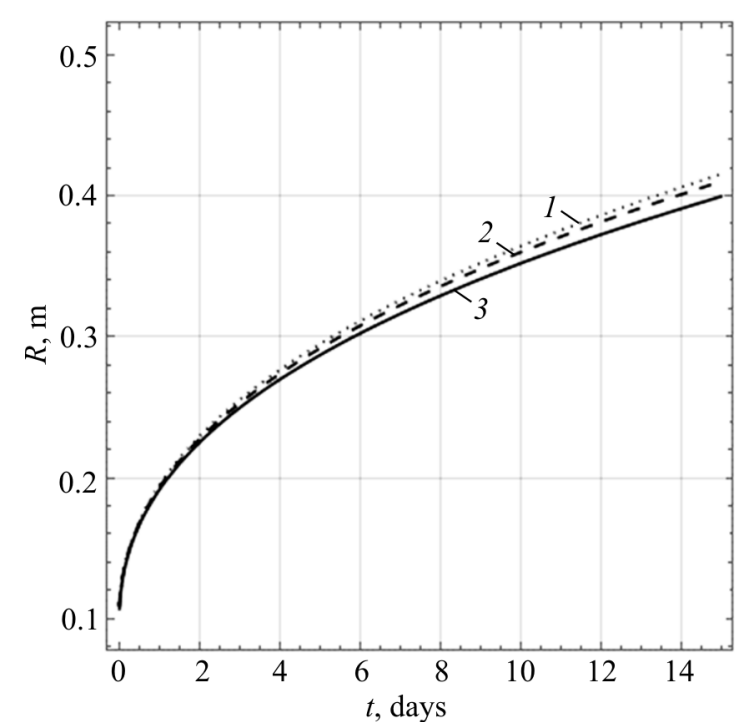

Fig. 3. Time diagram of the phase transition front using various approximating functions in the cooling zone:

1 - exponential form; 2 - trigonometric form;

3 - form of integral exponential function

\section{An algorithm to solve inverse Stefan problem for the case of a single freezing column}

Previously it was mentioned in the paper, that the integral exponential function gives the strongest value from the bottom for the radius of the phase transition front for solving the direct Stefan problem. Since calculation of a thickness of an ice wall is made from measurements in control wells such a value looses its significance in analysis of the inverse Stefan problem.

Based on the condition (8) it is possible to write down the following temperature mismatch function in the control wells, which will later be a subject for a minimization procedure:

$$
I=\sum_{i}\left\|T_{e_{i}}(t)-T\left(r_{e_{i}}, t\right)\right\| \rightarrow \min
$$

The summation in the equation (13) is carried out on reference wells $e_{i}$.

In order to estimate the deviation of the solution from the required values on the time interval $\left[t_{1}, t_{2}\right]$ the following scalar quantity (norm in Lebesgue space) is accepted as a norm in formula (14) $L_{2}[25]$ :

$$
\|f(t)\|_{\left[t_{1}, t_{2}\right]}=\sqrt{\frac{1}{T} \int_{t_{1}}^{t_{2}} f(t)^{2} d t .}
$$

It is required to determine the parameters by which the functional (13) is minimized. Classically [13], there are several inverse problems of heat transfer such as:

1) retrospective: initial conditions are adjustable parameters;

2) boundary: boundary conditions ensure the control;

3) coefficient: physical properties of the heat conducting medium are varied (identification of a thermal conductivity operator is performed).

Studies [21, 22, 26, 27] show, that during the construction of a mathematical model of ice wall formation physical properties of the rock massif and groundwater contained in them are least reliable. That is caused by heterogeneity of the real rock massif, imperfection of the methods for determination of physical and mechanical properties of the rock massif on the extracted core samples, statistical sample series are not enough etc. Due to the reasons mentioned, inverse Stefan problem is considered in this study to be a coefficient problem. Up to the four independent thermophysical parameters of the medium as variable parameters can be adopted. This is caused by the fact that the solution $T(r, \varphi, t)$ depends on the four dimensionless numbers problem (1)-(7) such as Fourier in the ice zone $\mathrm{Fo}_{1}$ and cooling zone $\mathrm{Fo}_{2}$, Stefan in the ice zone $\mathrm{Ste}_{1}$ and cooling zone $\mathrm{Ste}_{2}$.

The paper considers the case of two variable thermophysical parameters such as the thermal conductivities of the medium in the ice zone $k_{1}$ and cooling zone $k_{2}$. A valid range is set for each of these parameters $k_{1} \in\left[k_{1}^{\min }, k_{1}^{\max }\right] \quad$ and $k_{2} \in\left[k_{2}^{\min }, k_{2}^{\max }\right]$ based on engineering and geological surveys.

Thus, problem statement represent minimization of the functional (13) in terms of thermal conductivity parameters $k_{1}$ and $k_{2}$ of the rock massif.

There was an iterative algorithm for solving the inverse Stefan problem chosen in the paper which ia as follows:

1. Determination of initial approximations for minimization parameters - heat conductions $k_{1}$ and $k_{2}$.

2. A numerical calculation of a dependence of a phase transition front radius $r_{p h}(t)$ on time using the explicit $4^{\text {th }}$ order Runge-Kutta method. 
3. Numerical integration of temperature mismatches $\left\|T_{e_{i}}(t)-T\left(r_{e_{i}}, t\right)\right\|$ for each reference well for current thermal conductivities $\left(k_{1}, k_{2}\right)$ and conductions deviated from the $\left(k_{1}, k_{2}\right)$ on the small value $\left(k_{1}+\Delta k, k_{2}\right)$ and $\left(k_{1}, k_{2}+\Delta k\right)$. Calculation of an integral of mismatches $I$ and its first derivatives. Comparison of the error integral $I$ with the required accuracy $I_{a c c}$. If $I<I_{a c c}$ then exit from the procedure and completion of the calculation.

4. Calculation of the increments for minimization parameters is performed by the gradient descent method [28, 29]. Setting new values of heat conductivitys $k_{1}$ and $k_{2}$. Check of the
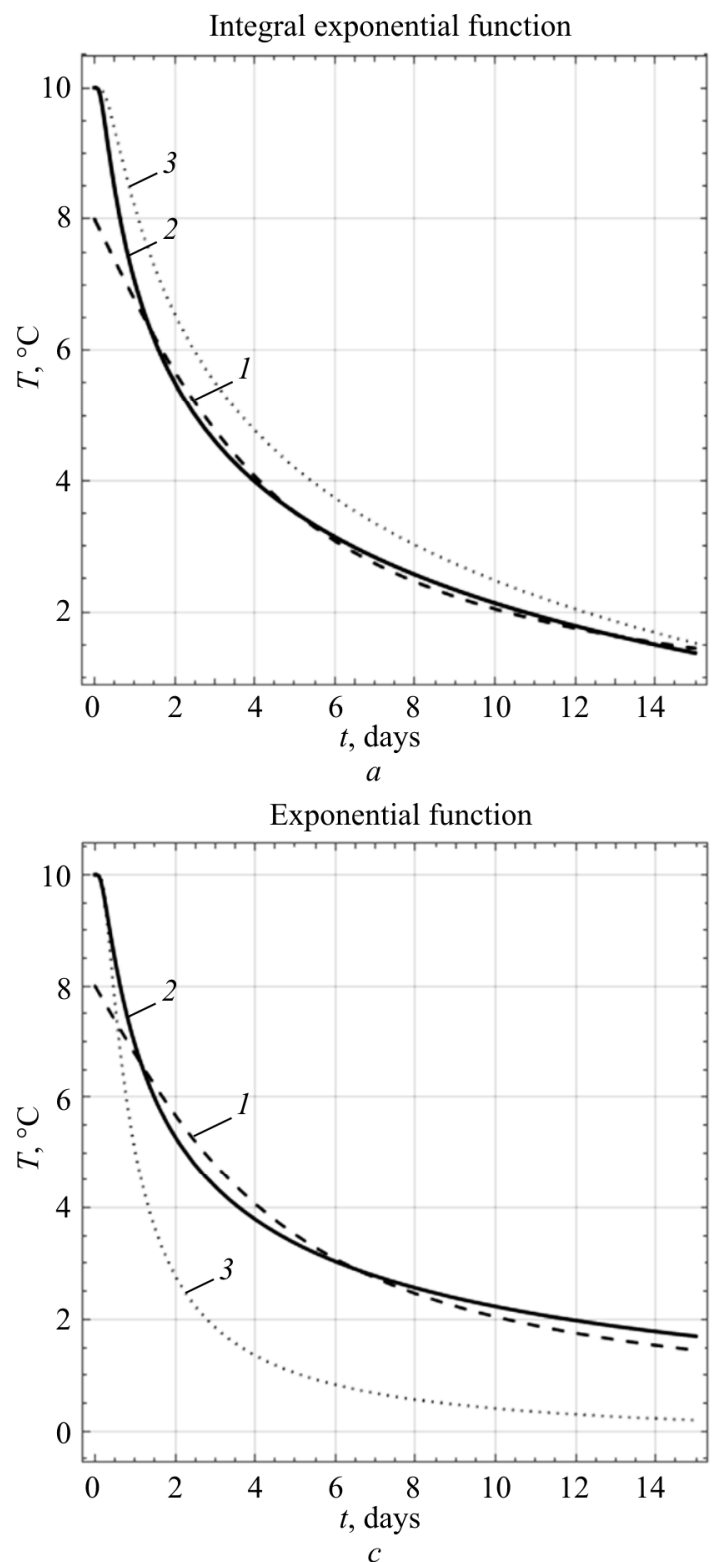

new values of thermal conductivities for the limiting minimum and maximum values.

5. Return to the step 2 (new iteration).

\section{Example of solution of inverse Stefan problem. Case of a single control well}

The Fig. 4 and 5 present an example of solution for the inverse Stefan problem by minimization of an approximating function for the case of a single control well with a given temperature dependence with time in the form

$$
T_{e_{i}}(t)=8-5 \arctan \left(\frac{t}{345600}\right) \text {. }
$$

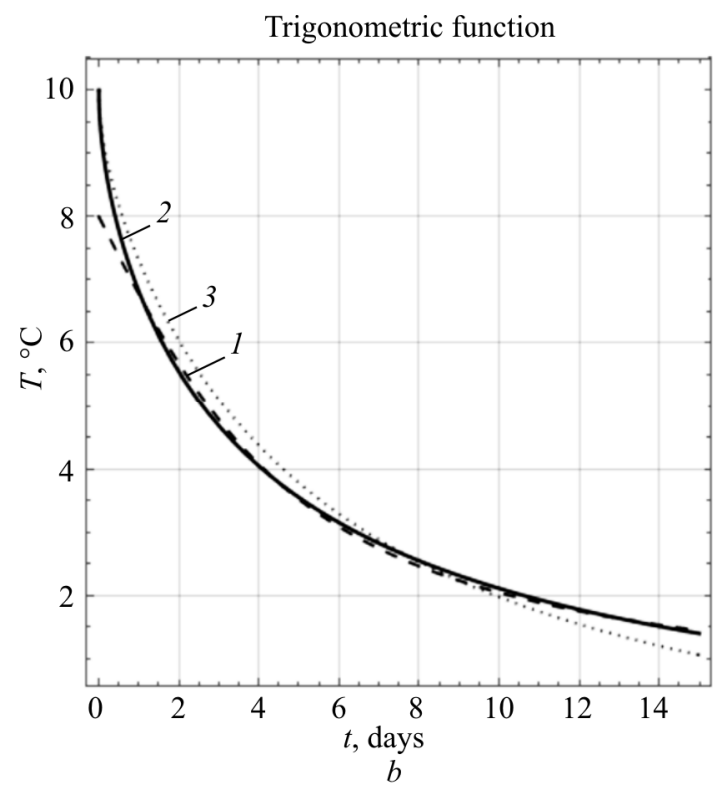

Fig. 4. Time diagram of temperature of the massif at the surface of a control well: 1 - objective function; 2 - initial approximation of the solution; 3 - solution of the inverse Stefan problem by minimization of an approximating function 
Input parameters of the problem are as follows: thermal conductivity of the medium in the ice zone $2,5 \mathrm{~W} /\left(\mathrm{m} \cdot{ }^{\circ} \mathrm{C}\right)$; thermal conductivity of the medium in the cooling zone $1,5 \mathrm{~W} /\left(\mathrm{m} \cdot{ }^{\circ} \mathrm{C}\right)$; specific heat of the medium in the ice zone $800 \mathrm{~J} /\left(\mathrm{kg} \cdot{ }^{\circ} \mathrm{C}\right)$; specific heat of the medium in the cooling zone $850 \mathrm{~J} /\left(\mathrm{kg} \cdot{ }^{\circ} \mathrm{C}\right)$; density of the medium $2000 \mathrm{~kg} / \mathrm{m}^{3}$; phase transition temperature $0{ }^{\circ} \mathrm{C}$; specific heat of ice melting $330 \mathrm{~kJ} / \mathrm{kg}$; massif moisture $0,3 \mathrm{~kg} / \mathrm{kg}$; freezing temperature of the well wall $-20{ }^{\circ} \mathrm{C}$; temperature of undisturbed rock massif at a distance $+10{ }^{\circ} \mathrm{C}$.

Integral exponential, trigonometric and exponential functions are considered as approximating ones. It was possible to achieve good convergence of the solution for all three types of functions. Nevertheless, temperature distributions that result values of thermal conductivity coefficients and thicknesses of an ice wall are essentially different (see Fig. 4, 5).

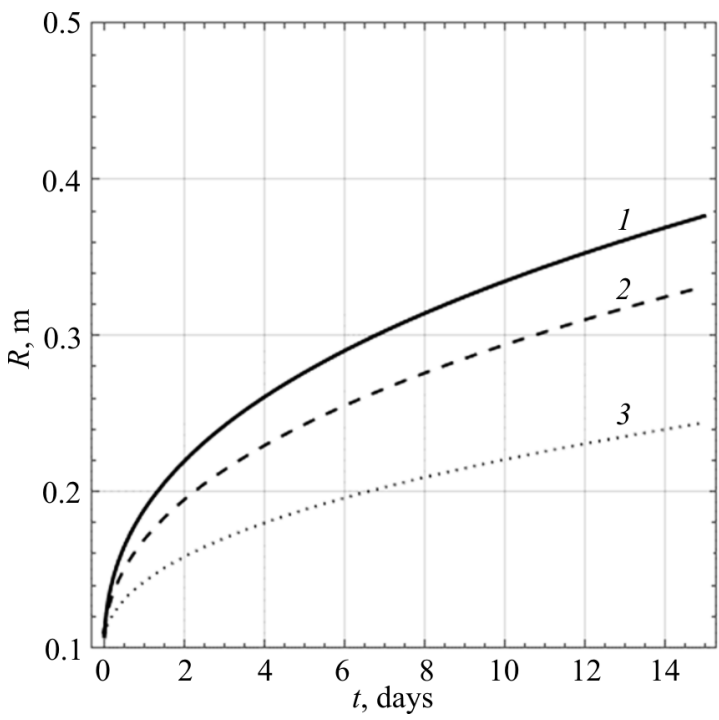

Fig. 5. Solution of the inverse Stefan problem;

a time diagram of the phase transition front with use of various approximating functions in the cooling zone: 1 - integral exponential function type; 2 - trigonometric type; 3 - exponential type

As can be seen from the graphs on the Fig. 4, each solution $T=T(r, t)$ would apapproach a given function $T_{e}(t)$ as close as it was possible considering the limits of a functional type of this solution as well as boundatry and initial conditions. Differences in a functional type of the solution also led to differences in the resulting coefficients of thermal conductivity of the medium, that iterative procedures of the ISP solution algorithm (Table 1) and differences in thicknesses of an ice wall converged to (see Fig. 5).

Table 1

Heat conductivity coefficients

obtained by solving the ISP

\begin{tabular}{|l|c|c|c|}
\hline $\begin{array}{c}\text { Thermal } \\
\text { conductivity } \\
\text { coefficient }\end{array}$ & $\begin{array}{c}\text { Integral } \\
\text { exponential } \\
\text { function }\end{array}$ & $\begin{array}{c}\text { Exponential } \\
\text { function }\end{array}$ & $\begin{array}{c}\text { Trigonometric } \\
\text { function }\end{array}$ \\
\hline Ice zone & 3.5 & 3.0 & 2.8 \\
\hline Cooling zone & 2.6 & 0.6 & 1.5 \\
\hline
\end{tabular}

If we assume that the curve $r_{p h}(t)$ is valid for the integral exponential function, then the error in determination of thickness of an ice wall on the $15^{\text {th }}$ day for the selected calculation parameters using trigonometric and exponential functions is 20 and $50 \%$ respectively.

\section{A solution for inverse Stefan problem for the case of a set of freezing columns}

The proposed method for solving the inverse Stefan problem can be transferred to the case of a set of freezing columns and set of control thermal wells (Fig. 6).

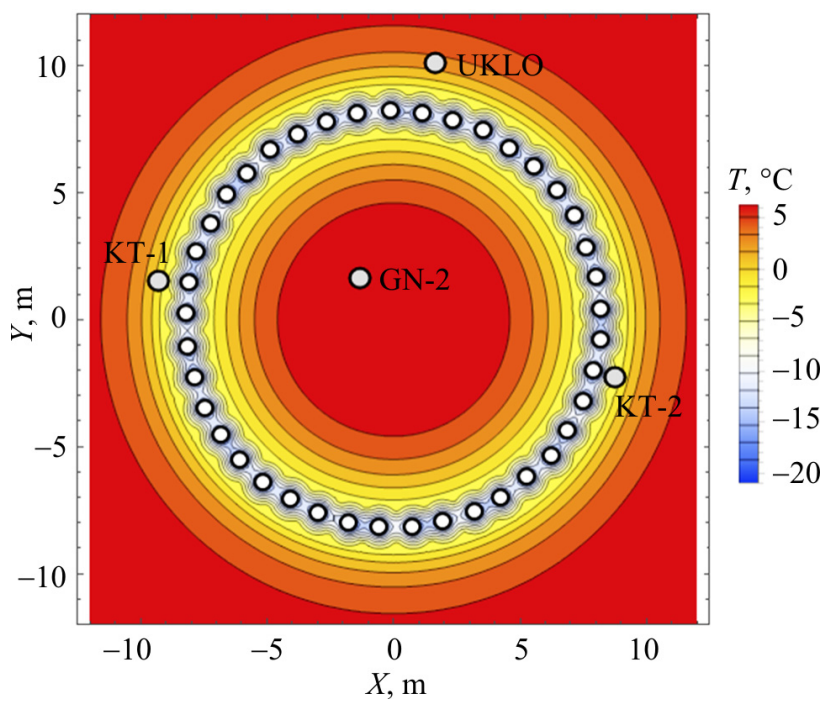

Fig. 6. Distribution of temperatures in a horizontal section of the rock massif obtained as a result of solving the inverse Stefan problem

For the case of a set of freezing columns the approximate dependence of temperature on time, spatial coordinates and thermophysical parameters of the problem can be determined as given below. The calculation area is divided into three subarea such as:

1) ice zone near the freezing columns, 
2) cooling zone inside the contour of freezing columns,

3) cooling zone outside the contour of freezing columns.

A functional type of the temperature field in the ice zone near the freezing columns is still determined by the formula (9). Since the function (9) is potential type, then its superposition for a set of wells does not lead to violation of the equality in the equation (1):

$$
\begin{gathered}
T_{1}=\sum_{i=1}^{N_{f}}\left[T_{w}-T_{p h}-\frac{T_{w}}{\ln \left(r_{p h} / r_{w i}\right)} \ln \left(r / r_{w i}\right)\right] \times \\
\times c_{c a l}+T_{p h} .
\end{gathered}
$$

Here $N_{f}$ is for a number of freezing columns; $r_{w i}$ is for a radius vector of a center of a freezing column No. $i ; r_{p h}$ is for half-thickness of an ice wall (distance from the front of the phase transition to the contour of freezing columns); $c_{c a l}$ is for a calibration parameter introduced to satisfy the fulfilment of the boundary condition (5).

Such a method uses an approach according to which inner and outer phase transition fronts move with the same velocity. The approach allows operating with a half-thickness of an ice wall $r_{p h}$, which is equal to the distance from any of two phase-transition fronts to the contour of freezing columns.

A functional type of the temperature field in the cooling zone outside the contour of freezing columns is determined by the function (12). The temperature field at a distance from the contour of freezing column becomes axisymmetric by several radii of the column $r_{w}$ (see Fig. 5). So, the temperature field in this problem becomes similar to a temperature field from a some single abstract freezing column with a radius equal near to the sum of the radius of the contour of freezing columns $r_{c}$ and current value of half-thickness of an ice wall $r_{p h}$ :

$$
T_{2}=T_{0}+\frac{T_{p h}-T_{0}}{\operatorname{Ei}\left(-\frac{\left(r_{c}+r_{p h}\right)^{2}}{4 a_{2} t}\right)} \operatorname{Ei}\left(-\frac{r^{2}}{4 a_{2} t}\right) .
$$

The functional type of the temperature field in the cooling zone inside a freezing column contour is determined using the Fourier-Bessel series [30]:

$$
\begin{gathered}
T_{2}=T_{p h}+\frac{2\left(T_{0}-T_{p h}\right)}{r_{c}-r_{p h}} \times \\
\times \sum_{i=1}^{N} \frac{J_{0}\left(\lambda_{i} r\right)}{\lambda_{i} J_{1}\left(\lambda_{i}\left(r_{c}-r_{p h}\right)\right)} \exp \left(-a_{2} \lambda_{i}^{2} t\right) .
\end{gathered}
$$

The number of terms in the Fourier series is determined based on the preliminary analysis of the convergence of the series for a given time. For the times when an ice wall is formed of $t \approx 10-100$ days 5-10 first members of Fourier series are converged.

The functions (16)-(18) are joined on inner and outer fronts of the phase transition. There is in equations (16)-(18) a value of the phase transition radius $r_{p h}$, in the general case, is a problem's parameter. It can be considered as an optimization parameter or can be found from the numerical solving an ordinary first-order differential equation (3) after substituting the temperature gradients calculated from functions (16)-(18) into it.

It should be noted that within the frame of the proposed approach it is considered that freezing columns form a regular circular contour (no inclinometry). The proposed approach will have an additional error. The higher the inclinometry of wells the higher the error.

Then the temperature mismatch function in control wells is determined and minimized by the gradient descent method. As can be seen from the Fig. 6, distribution of temperatures in the horizontal section of the rock massif obtained for conditions of the shaft No. 1 of the mine being under construction at the Petrikovskiy Ore Mining and Processing Plant.

The Fig. 6 also shows a contour of 41 freezing columns and four control wells such as KT-1 $\left(-1,5^{\circ} \mathrm{C}\right), \mathrm{KT}-2\left(-1,1{ }^{\circ} \mathrm{C}\right)$, UKLO $\left(2,5^{\circ} \mathrm{C}\right), \mathrm{GN}-2$ $\left(5,7^{\circ} \mathrm{C}\right)$. Temperatures of control wells correspond to the freezing time of 60 days.

Input parameters of the problem are as follow: phase transition temperature $-2.1{ }^{\circ} \mathrm{C}$; temperature of walls of a freezing well $-20^{\circ} \mathrm{C}$; temperature of undisturbed rock massif at a distance $+6.3{ }^{\circ} \mathrm{C}$; radius of the contour of freezing columns $8.2 \mathrm{~m}$; radius of a freezing column $0.17 \mathrm{~m}$; density of the medium $1960 \mathrm{~kg} / \mathrm{m}^{3}$; initial thermal conductivity of the medium in the ice zone $1.5 \mathrm{~W} /\left(\mathrm{m}^{\circ}{ }^{\circ} \mathrm{C}\right)$; initial thermal conductivity of the medium in the cooling 
zone $1.29 \mathrm{~W} /\left(\mathrm{m}^{\circ}{ }^{\circ} \mathrm{C}\right)$; specific heat of the medium in the ice zone $1421 \mathrm{~J} /\left(\mathrm{kg} \cdot{ }^{\circ} \mathrm{C}\right)$; specific heat of the medium in the cooling zone $1566 \mathrm{~J} /\left(\mathrm{kg} \cdot{ }^{\circ} \mathrm{C}\right)$.

As a result of minimization of the temperature mismatch functional it was found that thermal conductivities in the ice zone and cooling zone are equal to 1.24 and $0.97 \mathrm{~W} /\left(\mathrm{m} \cdot{ }^{\circ} \mathrm{C}\right)$ respectively. Thickness of an ice wall is $1.94 \mathrm{~m}$.

Temperature mismatch function at the end of the iterative procedure is $0.6{ }^{\circ} \mathrm{C}$. Null-value of the temperature mismatch function is caused by the reasons that are as follows:

- error of the numerical method;

- inconsistency of conditions (8) for four different wells.

\section{The case of incompatibility of temperature measurements by several control wells}

During the searching for a solution of the inverse Stefan problem for the case of several control wells there is a question arised about the incompatibility of conditions (8) for different wells. For example, let us consider the problem of a symmetrical ice wall formed near a single well and two control wells located at the same distance from different sides of the freezing column (Fig. 7 ). It is said that they have different temperature values of the form (8) in them. It will be useless to satisfy both of these conditions at the same time when solving the inverse Stefan problem.

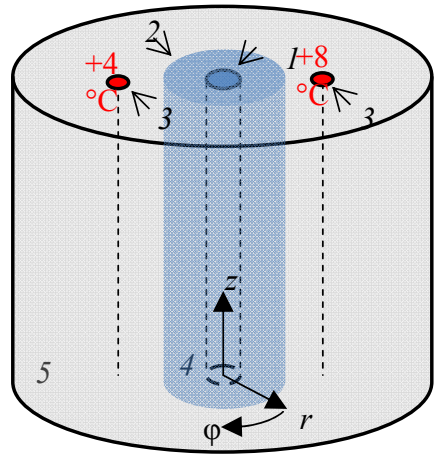

Fig. 7. Geometrical model of a rock massif with a freezing column and two control wells: 1 - freezing column; 2 - front of the phase transition; 3 - control

wells; 4 - ice zone; 5 - zone of rock massif cooling

If we construct a functional of (13) type, that represents a sum of the mismatches for all control wells and minimize it in any correct way, then it is most likely possible to obtain some average solution that somehow disagrees with each of control wells', but given a minimum discrepancy over the all wells in general. Such a formal approach is most likely to be used when the inconsistency of temperatures over the all control wells is small and average solution obtained from minimizing the formally constructed functional (13) slightly mismatches each of the control wells' values.

However, there are often cases of highly inconsistent temperature readings on the control wells in practice. That may be caused by both the error of a measurement procedure in control wells and errors in measured thermophysical parameters of the rock massif (inhomogeneity of properties), inaccuracy of technology variables (temperature and flow rate of coolant injection into freezing columns). Often it is impossible to obtain more accurate information about these parameters onfield for real shafts under construction.

These facts indicate the need to involve a probabilistic approach for analyzing the thickness of an ice wall. In the frame of the present approach an ice wall will be represented by a probability function of time $t$ and distance $r$ from a freezing column (or the contour of freezing columns).

In order to implement the probabilistic approach, it is necessary to assume some hypotheses about the nature of mismatch of model temperature distribution with real experimentally measured for each well values. The hypothesis on unreliable readings of wells and hypothesis on a natural anomaly are possible options.

1. Hypothesis on unreliable readings of wells. It is considered, that the mismatch is connected to the error in experimental measurements and is caused by a small number of control wells in comparison with their total number. Since it is often necessary to deal with 3-5 control wells in practice, it can be assumed that the mismatch is caused by one control well. To eliminate the high mismatch of the model temperature distribution with a real one, it is proposed to remove the most controversial control well from consideration.

In case the error of the most controversial test well is significant the well can be excluded by manual processing. In those cases where it is not possible to determine in advance a control well with unreliable data, it is suggested to perform a successive discarding of each well from consideration and minimize the functional (13) 
$N$ times for each of combination of $N-1$ wells. The output will be a sample of $N$ radius $r_{p h}(t)$ of an ice wall and $N$ corresponding to them lowest achievable mismatches (a value of the functional (13) within each combination of N-1 wells. Based on received mismatches $I_{i}$ a function of thickness distribution probability $\left(r_{i}, P_{i}\right)$ of the ice wall in points is calculated (Table 2).

$$
\begin{gathered}
p_{i}=\frac{1-\sum_{j \neq i} I_{j}^{2}}{\sum_{j} I_{i}^{2}}, \\
P_{i}=\sum_{j} p_{j} \theta\left(r_{j}-r_{i}\right) .
\end{gathered}
$$

Table 2

Calculation of a probability of thickness of an ice wall within the hypothesis of unreliable readings of wells

\begin{tabular}{|l|c|c|c|c|}
\hline \multirow{2}{*}{\multicolumn{1}{|c|}{ Parameter }} & \multicolumn{4}{|c|}{ Number of excluded well } \\
\cline { 2 - 5 } & 1 & 2 & 3 & 4 \\
\hline Radius of an ice wall $r_{i}, \mathrm{~m}$ & 0.25 & 0.28 & 0.29 & 0.34 \\
\hline Mismatch $I_{i},{ }^{\circ} \mathrm{C}$ & 0.582 & 0.408 & 0.336 & 0.142 \\
\hline Probability, \% & 100 & 84 & 59 & 32 \\
\hline
\end{tabular}

Graphically, the probability distribution function for thickness of an ice wall is shown on the Fig. 8.

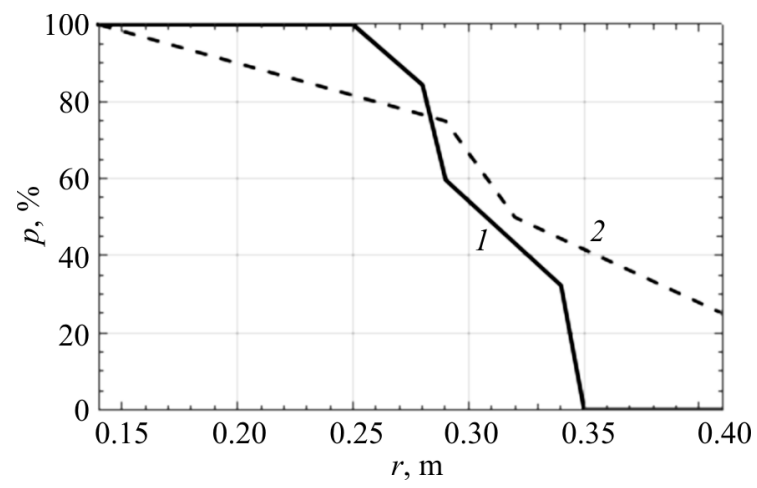

Fig. 8. Functions of an ice wall thickness $r$ distribution: 1 - hypothesis on unreliable readings of wells; 2 - hypothesis on a natural anomaly

2. Hypothesis on a natural anomaly. Like the previous one, this hypothesis suggests that the mismatch is caused by a small number of control wells in comparison with their total number. However, here there is a significant difference. The least reliable wells are not excluded but taken into account as well in calculation of thickness of an ice wall.
A strong deviation in readings of a single control well compared with the rest can be caused not only by the error in readings. It can also be associated with some geological disturbance (crack, foreign inclusion in the rocks), leading to a significant disruption in homogeneity of physical properties of the rock massif in the local area. That, in turn, can slow down formation rate of an ice wall around the contour of freezing wells in the local zone affected by such a geological disturbance. Therefore, thickness of an ice wall in that local zone may be lower than in the rest of the contour of freezing wells.

It is proposed to construct $N$ solutions of the inverse Stefan problem for each control well separately. As a result, a set of ice wall thicknesses was obtained. At the output, we also obtain a sample of $N$ radii $r_{p h}(t)$ of an ice wall and $N$ corresponding to them minimum achievable discrepancies for each well. It is considered that geological disturbances have equal probabilities to be. We calculate that probabilities $P_{i}$ equally for each well separately from the obtained mismatches $I_{i}$. In our case of consideration of each control well mismatches have to be small. The table 3 presents the results of calculation of the radius $r_{i}$ and probabilities that the thickness of an ice wall is equal to at least one radius $r_{i}$, with taken into account the hypothesis on a natural anomaly.

Table 3

Calculation of the probability of an ice wall thickness within the hypothesis on a natural anomaly

\begin{tabular}{|l|c|c|c|c|}
\hline \multirow{2}{*}{\multicolumn{1}{|c|}{ Parameter }} & \multicolumn{4}{|c|}{ Number of considered well } \\
\cline { 2 - 5 } & 1 & 2 & 3 & 4 \\
\hline Radius of an ice wall $r_{i}, \mathrm{~m}$ & 0.41 & 0.32 & 0.29 & 0.14 \\
\hline Probability, \% & 25 & 50 & 75 & 100 \\
\hline
\end{tabular}

Functions of distribution of thickness of an ice wall $r$ for each of the two hypotheses considered are shown on the Fig. 8.

\section{Conclusion}

The present paper contains the study of the inverse Stefan problem with respect to the problem of monitoring the state of an ice wall during the shaft excavation. The main scientific results are as follows:

1. Mathematical statement of the direct and inverse Stefan problem for a horizontal layer of 
a rock massif with homogeneous and isotropic thermophysical properties.

2. The method that allows obtaining an approximate solution of the direct Stefan problem for a single freezing column with a small consumption of computational resources and for a case of random number of freezing columns located along a circular contour.

3. Numerical execution of the method for solving the inverse Stefan problem for the case of a single freezing column and case of a random number of freezing columns arranged along a circular contour.
4. Analysis of how the type of a function used to approximate the temperature field in the cooling zone affects the solution.

5. Calculation of the inverse Stefan problem for the conditions of mine shaft No. 1 of the mine under construction at the Petrikovskiy Ore Mining and Processing Plant.

6. Study and interpretation of mismatch measured in control wells, probabilistic analysis of the thickness of an ice wall.

The study was carried out with the financial support of the Russian Science Foundation in the framework of the scientific project No. 17-11-01204.

\section{References}

1. Romenskii A.A. Obosnovanie parametrov prokhodnicheskogo tsikla i ledoporodnogo ograzhdeniia pri stroitel'stve vertikal'nykh stvolov [Substantiation of the parameters of the tunnel and the ice rock wall in the construction of vertical trunks]. Ph. D. thesis. Moscow, 1983, $227 \mathrm{p}$.

2. Pravila bezopasnosti pri stroitel'stve podzemnykh sooruzhenii PB 03-428-02 [Safety rules for the construction of underground structures $\mathrm{PB}$ 03-428-02]. Utverzhdeny Postanovleniem Gosgortekhnadzora RF ot 02.11.2001 no. 49, $167 \mathrm{p}$.

3. Levin L.Iu., Semin M.A., Zaitsev A.V. Kontrol' i prognoz formirovaniia ledoporodnogo ograzhdeniia $\mathrm{s}$ ispol'zovaniem optovolokonnykh tekhnologii [Monitoring and forecasting the formation of the ice rock wall using fiber-optic technology]. Strategiia i protsessy osvoeniia georesursov. Sbornik nauchnykh trudov. Perm', 2016, pp.236-238.

4. Levin L.Iu., Zaitsev A.V., Semin M.A. Kontrol' teplovogo rezhima porodnogo massiva na osnove primeneniia optovolokonnykh tekhnologii monitoringa temperatur $\mathrm{v}$ skvazhinakh [Control of the thermal regime of the rock massif based on the application of fiber-optic technologies for monitoring temperatures in wells]. Gornoe ekho, 2016, no.1(62), pp.35-37.

5. Trupak N.G. Zamorazhivanie gornykh porod pri prokhodke stvolov [Freezing of rocks when drilling trunks]. Moscow, Ugletekhizdat, 1954, $896 \mathrm{p}$.

6. Trupak N.G. Zamorazhivanie gruntov v podzemnom stroitel'stve [Freezing of soils in underground construction]. Moscow, Nedra, 1974, 280 p.

7. Man'kovskii G.I. Spetsial'nye sposoby prokhodki gornykh vyrabotok [Special methods for excavating mine workings]. Moscow, Ugletekhizdat, 1958, 454 p.

8. Dolgov O.A. Metodika rascheta protsessa zamorazhivaniia gornykh porod pri prokhodke stvolov shakht sposobom zamorazhivaniia na bol'shuiu glubinu [Method for calculating the process of freezing rocks when drilling shafts through a method of freezing to great depths]. Zamorazhivanie gornykh porod pri prokhodke stvolov shakht. Moscow, Izdatel'stvo Akademii nauk SSSR, 1961, pp.9-64.

9. Dmitriev A.P., Goncharov S.A. Termodinamicheskie protsessy $\mathrm{v}$ gornykh porodakh [Thermodynamic processes in rocks]. Moscow, Nedra, 1990, $360 \mathrm{p}$.

10. Bel'ferman M.U. Temperaturnoe pole ledoporodnogo ograzhdeniia shakhtnykh stvolov pri dvukhriadnom raspolozhenii zamorazhivaiushchikh kolonok [The temperature field of the ice rock wall of shaft shafts with a two-row arrangement of freezing columns]. Voprosy organizatsii $i$ mekhanizatsii gornoprokhodcheskikh rabot. Moscow, Institut gornogo dela imeni A.A. Skochinskogo, 1976, p.109-116.

11. Harris J.S. Ground freezing in Practice. Thomas Telford Limited, 1995, $290 \mathrm{p}$.

12. Andersland O.B., Ladanyi B. An introduction to frozen ground engineering. Springer US, 1994, $352 \mathrm{p}$.

13. Alifanov O.M. Obratnye zadachi teploobmena [Inverse heat transfer problems]. Moscow, Mashinostroenie, $1988,280 \mathrm{p}$.

14. Tikhonov A.N., Arsenin V.Y. Solution of ill-posed problems. Washington, DC, Winston \& Sons, 1977, 258 p.

15. Vabishchevich P.N., Vasil'eva M.V., Pavlova N.V. Chislennoe modelirovanie termostabilizatsii fil'truiushchikh gruntov [Numerical modeling of thermostabilization of filtering soils]. Matematicheskoe modelirovanie, 2014, vol.26, no.9, pp.111-125.

16. Musakaev N.G., Romaniuk S.N., Borodin S.L. Chislennoe issledovanie zakonomernostei dvizheniia fronta fazovogo perekhoda $\mathrm{v}$ mnogoletnemerzlykh porodakh [Numerical study of the laws governing the motion of the phase transition front in permafrost rocks]. Izvestiia vuzov. Neft' $i$ gaz, 2011, no.6, pp.122-128.

17. Borodin S.L. Chislennye metody resheniia zadachi Stefana [Numerical methods for solving the Stefan problem] Tyumen State University Herald. Physical and Mathematical Modeling. Oil, Gas, Energy. 2015, vol.1, no.3, pp.164-175. 
18. Goldman N. Inverse Stefan problems. Springer Science \& Business Media, 2012, 412 p.

19. Mikkola M., Hartikainen J. Mathematical model of soil freezing and its numerical application. International Journal for Numerical Methods in Engeneering, 2001, vol.52, pp.543-557. DOI: 10.1002/nme.300

20. Kruschwitz J., Bluhm J. Modeling of ice formation in porous solids with regard to the description of frost damage. Computational Material Science, 2005, vol.3-4, pp.407-417. DOI: 10.1016/j.commatsci.2004.09.025

21. Razrabotka iskhodnykh dannykh dlia proekta prokhodki stvolov, $\mathrm{v}$ tom chisle: iskhodnye dannye po skipovomu stvolu [Development of initial data for the project of sinking of trunks, including initial data on the skip shaft]. Otchet o NIR № 58-12, book 1, etap 10.1 . Belgorkhimprom, 2013, 192 p.

22. Analiz i obobshchenie rezul'tatov. Vyiavlenie zakonomernostei variatsii teplofizicheskikh i prochnostnodeformatsionnykh kharakteristik gornykh porod $\mathrm{V}$ vertikal'nom i gorizontal'nom napravleniiakh na uchastke petrikovskogo gorno-obogatitel'nogo kompleksa. Formirovanie bazy dannykh [Analysis and synthesis of the results. Identification of the regularities in the variation of the thermophysical and strength-deformation characteristics of rocks in the vertical and horizontal directions in the area of the Petrikov Ore Mining and
Processing Complex. Formation of the database]. Otchet o NIR №58-12, etap 30.2.6. Belgorkhimprom, 2013, 230 p.

23. Karslou G., Eger D. Teploprovodnost' tverdykh tel [Thermal conductivity of solids]. Moscow, Nauka, $1964,488 \mathrm{p}$.

24. Butcher J.C. Numerical methods for ordinary differential equations. New York, John Wiley \& Sons, 2008, 440 p.

25. Maddox I.J. Elements of functional analysis. 2nd ed. Cambridge, 1988, 256 p.

26. Alexiades V., Solomon A.D. Mathematical modeling of melting and freezing processes. Washington DC, Hemisphere, 1993, 336 p.

27. Hu H., Argyropoulos S.A. Mathematical modelling of solidification and melting: a review. Modelling and Simulation in Materials Science and Engineering, 1996, vol. 4, pp.371396. DOI: 10.1088/0965-0393/4/4/004

28. Vasil'ev F.P. Metody optimizatsii [Optimization methods]. Moscow, Faktorial Press, 2002, 824 p.

29. Jarny Y., Ozisik M.N., Bardon J.P. A general optimization method using adjoint equation for solving multidimensional inverse heat conduction. International Journal of Heat and Mass Transfer, 1991, vol.34, no.11, pp.2911-2919. DOI: 10.1016/0017-9310(91)90251-9

30. Ozisik M.N. Inverse heat transfer: fundamentals and applications. CRC Press, 2000, 352 p.

\section{Библиографический список}

1. Роменский А.А. Обоснование параметров проходнического цикла и ледопородного ограждения при строительстве вертикальных стволов: дис. ... канд. техн. наук. - М., 1983. - 227 с.

2. ПБ 03-428-02. Правила безопасности при строительстве подземных сооружений: утв. Постановлением Госгортехнадзора РФ от 02.11.2001 № 49. M., 2002. - $167 \mathrm{c}$.

3. Левин Л.Ю., Семин М.А., Зайцев А.В. Контроль и прогноз формирования ледопородного ограждения с использованием оптоволоконных технологий // Стратегия и процессы освоения георесурсов: сб. науч. тр. - Пермь, 2016. - С. 236-238.

4. Левин Л.Ю., Зайцев А.В., Семин М.А. Контроль теплового режима породного массива на основе применения оптоволоконных технологий мониторинга температур в скважинах // Горное эхо. - 2016. - № 1 (62). - С. 35-37.

5. Трупак Н.Г. Замораживание горных пород при проходке стволов. - М.: Углетехиздат, 1954. - 896 с.

6. Трупак Н.Г. Замораживание грунтов в подземном строительстве. - М.: Недра, 1974. - 280 с.

7. Маньковский Г.И. Специальные способы проходки горных выработок. - М.: Углетехиздат, 1958. - 454 с.

8. Долгов О.А. Методика расчета процесса замораживания горных пород при проходке стволов шахт способом замораживания на большую глубину // Замораживание горных пород при проходке стволов шахт. - М.: Изд-во Академии наук СССР, 1961. - С. 9-64.
9. Дмитриев А.П., Гончаров С.А. Термодинамические процессы в горных породах. - 2-е изд., перераб. и доп. - М.: Недра, 1990. - 360 с.

10. Бельферман М.У. Температурное поле ледопородного ограждения шахтных стволов при двухрядном расположении замораживающих колонок // Вопросы организации и механизации горнопроходческих работ / Ин-т горн. дела им. А.А. Скочинского. - М., 1976. - С. 109-116.

11. Harris J.S. Ground freezing in practice. - Thomas Telford Limited, 1995. - 290 p.

12. Andersland O.B., Ladanyi B. An introduction to frozen ground engineering. - Springer US, 1994. - 352 p.

13. Алифанов О.М. Обратные задачи теплообмена. М.: Машиностроение, 1988. - 280 с.

14. Tikhonov A.N., Arsenin V.Y. Solution of ill-posed problems. - Washington DC: Winston \& Sons, 1977. - 258 p.

15. Вабищевич П.Н., Васильева М.В., Павлова Н.В. Численное моделирование термостабилизации фильтрующих грунтов // Математическое моделирование. - 2014. - Т. 26, № 9. - С. 111-125.

16. Мусакаев Н.Г., Романюк С.Н., Бородин С.Л. Численное исследование закономерностей движения фронта фазового перехода в многолетнемерзлых породах // Известия вузов. Нефть и газ. - 2011. - № 6. - С. 122-128.

17. Бородин С.Л. Численные методы решения задачи Стефана // Вестник Тюменского государственного университета. Физико-математическое моделирование. Нефть, газ, энергетика. - 2015. - Т. 1, № 3. - С. 164-175. 
18. Goldman N. Inverse Stefan problems. - Springer Science \& Business Media, 2012. - 412 p.

19. Mikkola M., Hartikainen J. Mathematical model of soil freezing and its numerical application // International Journal for Numerical Methods in Engeneering. - 2001. Vol. 52. - P. 543-557. DOI: 10.1002/nme.300

20. Kruschwitz J., Bluhm J. Modeling of ice formation in porous solids with regard to the description of frost damage // Computational Material Science. - 2005. - Vol. 3-4. P. 407-417. DOI: 10.1016/j.commatsci.2004.09.025

21. Разработка исходных данных для проекта проходки стволов, в т.ч.: исходные данные по скиповому стволу: отчет о НИР № 58-12, книга 1, этап 10.1. / ОАО «Белгорхимпром». - Минск, 2013. - 192 с.

22. Анализ и обобщение результатов. Выявление закономерностей вариации теплофизических и прочностно-деформационных характеристик горных пород в вертикальном и горизонтальном направлениях на участке Петриковского горно-обогатительного комплекса. Формирование базы данных: отчет о НИР № 58-12, этап 30.2.6. / ОАО «Белгорхимпром». - Минск, 2013. - 230 с.

23. Карслоу Г., Егер Д. Теплопроводность твердых тел. - М.: Наука, 1964. - 488 с.
24. Butcher J.C. Numerical methods for ordinary differential equations. - New York: John Wiley \& Sons, 2008. $-440 \mathrm{p}$.

25. Maddox I.J. Elements of functional analysis. 2nd ed. - Cambridge, 1988. - $256 \mathrm{p}$.

26. Alexiades V., Solomon A. D. Mathematical modeling of melting and freezing processes. - Washington DC: Hemisphere, 1993. $-336 \mathrm{p}$.

27. Hu H., Argyropoulos S.A. Mathematical modelling of solidification and melting: a review // Modelling and Simulation in Materials Science and Engineering. - 1996. - Vol. 4. - P. 371-396. DOI: $10.1088 / 0965-0393 / 4 / 4 / 004$

28. Васильев Ф.П. Методы оптимизации. - М.: Факториал Пресс, 2002. - 824 с.

29. Jarny Y., Ozisik M.N., Bardon J.P. A general optimization method using adjoint equation for solving multidimensional inverse heat conduction // International Journal of Heat and Mass Transfer. 1991. - Vol. 34, № 11. - P. 2911-2919. DOI: $10.1016 / 0017-9310(91) 90251-9$

30. Ozisik M.N. Inverse heat transfer: fundamentals and applications. - CRC Press, 2000. -352 p.

Please cite this article in English as:

Levin L.Yu., Syomin M.A., Parshakov O.S., Kolesov E.V. Method for solving inverse Stefan problem to control ice wall state during shaft excavation. Perm Journal of Petroleum and Mining Engineering, 2017, vol.16, no.3, pp.255-267. DOI: 10.15593/2224-9923/2017.3.6

Просьба ссылаться на эту статью в русскоязычных источниках следующим образом:

Метод решения обратной задачи Стефана для контроля состояния ледопородного ограждения при проходке шахтных стволов / Л.Ю. Левин, М.А. Семин, О.С. Паршаков, Е.В. Колесов // Вестник Пермского национального исследовательского политехнического университета. Геология. Нефтегазовое и горное дело. - 2017. - Т.16, №3. - С.255-267. DOI: 10.15593/2224-9923/2017.3.6 